\title{
Ny overordnet del av læreplanen for skolen
}

1. september 2017 ble det vedtatt ny overordnet del av lareplanen for skolen. Utkastet var på høring våren 2017, og det ble levert mange høringssvar der flere rommet nokså store og omfattende bemerkninger til både form og innhold. Basert på gjennomlesing $a v$ en god del høringssvar presenterer vi her noe av det som ble meldt inn $i$ høringsrunden, med korte betraktninger fra forfatterne om hvordan det ble fulgt opp i den vedtatte planen. Tekstene presenterer noe av det som er nytt og omdiskutert, og gir et innblikk $i$ noe av høringsprosessen. Det handler om elevsyn, inkludering, mangfold, laringssyn, samarbeid med hjemmet, det varslede verdiløftet og de nye tverrfaglige emnene. Innleggene er signert ansatte fra Utdanningsforbundet, NTNU, Det teologiske menighetsfakultetet, Universitetene i Oslo og Stavanger, IKO og NLA Høgskolen.

Den nye planen kalles ikke lenger Generell del av lareplanen, men Overordnet del verdier og prinsipper for grunnopplaringen. Stilnivået og oppbyggingen er svart annerledes enn i den foregående planen. Denne starter med gjengivelse av formålsparagrafen, er delt inn i kapitlene «Opplaringens verdigrunnlag», «Prinsipper for laring, utvikling og danning» og «Prinsipper for skolens praksis», og de ulike delkapitlene starter med «skolen skal»-formuleringer. Helt nye tema er tre tverrfaglige emner samt profesjonsfellesskap og skoleutvikling.

\section{Elevsyn, inkludering og mangfold}

Av NiNA NoRDVIK, seniorrådgiver i Utdanningsforbundet. E-post: nina.nordvik@utdanningsforbundet.no

Utdanningsforbundet leverte en omfattende høringsuttalelse til regjeringens utkast til Overordnet del - verdier og prinsipper for grunnopplæringen. Vi var særlig opptatt av at Overordnet del må ta høyde for hvor sammensatt elevgruppen er. Vi var videre opptatt av at Overordnet del må fremme et nyansert begrep om mangfold.

\section{SYN PÅ ELEVEN OG PÅ LÆRING}

Formålsparagrafen sier at skolen og lærebedriften skal møte alle elever og lærlinger med tillit, respekt og krav, og gjennom utfordringer fremme danning og lærelyst. 
Utdanningsforbundet har i høringsprosessen understreket at Overordnet del og resten av læreplanverket må uttrykke et helhetlig syn på elevens læring og utvikling, som tar høyde for at et bredt register av uttrykksmåter er viktig for å utvikle kunnskap. Skolen må ha rom for elevens akademiske, reflekterende, skapende, kreative, musiske, lekende, praktiske og fysiske sider. Elever skal lære, erfare og oppleve gjennom både kognitiv, sosial og praktisk virksomhet. For barn er også leken en måte å uttrykke seg på.

Utdanningsforbundet bemerket også viktigheten av at grunnopplæringen skal skape tilhørighet for alle, ikke bare for «normaleleven» eller «den flinke». Dette er avgjørende for å hindre utenforskap og frafall, for det er dessverre ikke slik at alle elever i skolen føler seg verdsatt. Ulike unders $\emptyset$ kelser bekrefter dette. Elever har ulike læreforutsetninger, og kommer til skolen med svært forskjellige kulturelle, sosiale og verdibaserte tankesett. Dette kom ikke tydelig nok frem i høringsutkastet fra Kunnskapsdepartementet.

Den medvirkende eleven representerer en viktig kvalitet ved det norske, demokratiske skolesystemet. Utdanningsforbundet var i høringsprosessen opptatt av at Overordnet del ikke må fremstille elevene som passive mottakere av læring, utvikling og danning. Elevene må ikke bare beskrives gjennom hva de skal «få » eller «tilegne seg», men i stedet skrives inn i teksten som aktører som selvstendig håndterer fag og kultur.

\section{Omtalen av mangfold}

Det er viktig - og vanskelig - å finne inkluderende uttrykk for det fellesskapet skolen skal være. Men Overordnet del må bruke et språk som ikke ekskluderer noen.

I høringsprosessen la Utdanningsforbundet vekt på at utkastet hadde et for snevert begrep om mangfold, som la hovedvekt på kulturelt mangfold, og da i betydningen «ikke-norsk». Enkelte formuleringer i teksten kunne også tolkes som at dette kulturelle mangfoldet er noe som «må håndteres», snarere enn en ressurs. Utdanningsforbundet mener dette er uheldig, og fremmet i vår høringsuttalelse en forventning om at hele mangfoldet får en nyansert omtale, både som ressurs, utfordring og demokratisk virkelighet.

Høringsutkastet brukte også uttrykket «det norske samfunnet», som om dette er noe monokulturelt, enhetlig og ideelt. Slik er det ikke. Norsk kultur- og samfunnsliv påvirkes kontinuerlig av andre land og skikker. I høringsutkastet syntes «det norske» å være noe «de andre» skal strekke seg mot. Dette bidrar til en opplevelse av et skille mellom «oss » og «dem», noe Utdanningsforbundet mener er uheldig. 


\section{VEIEN VIDERE}

Utdanningsforbundets innspill i høringsprosessen har bidratt til å bevege utkastet $\mathrm{i}$ en positiv retning. Vi tror Overordnet del gir gode føringer for det videre arbeidet med fagfornyelsen, og vil få stor betydning i planlegging og gjennomføring av undervisningen i skolen.

\section{Verdiløft og læringssyn ${ }^{1}$}

Av CAmilla Stabel JøRgensen, førsteamanuensis ved Institutt for lorerutdanning (ILU), NTNU.

E-post: camilla.jorgensen@ntnu.no

\section{Verdiløft}

Det har vært forventninger til et varslet verdiløft. Fra Institutt for Lærerutdanning ved NTNU sitt perspektiv er et verdiløft velkomment. Vi stiller imidlertid spørsmål ved om høringsutkastet innfrir disse forventningene. Der mener vi det kommer til uttrykk noen forskyvninger i verdier, visjoner og mål som vi ikke oppfatter som et verdiløft. For oss ser det ut til at høringsutkastet legger større vekt på fremtidig kvalifisering enn elevens sosialisering og subjektivering $\mathrm{i}$ skolen. Dette blir særlig tydelig når vi sammenligner med generell del (fra L94/ L97). Dette er en utvikling vi ikke ønsker.

Det er uklart hva en verdi er i dokumentet og hvordan man kan forholde seg til verdier. Institutt for lærerutdanning leser forslaget som uttrykk for en sterk mål-middel-tenkning, der vekten ligger på at eleven skal forberedes på et liv etter skolen. Kvalifisering av barn og unge er selvsagt viktig, men det ser ut til at forslaget legger liten eller ingen vekt på skolens egenverdi. Denne tenkningen mener vi gir utfordringer når det er snakk om verdier. Kanskje kan en tydeliggjøring av mål på ulike nivå være en løsning? I det tilsvarende finske dokumentet finner vi mål på ulike nivå, for den spør hva som er siktemålene for skolen når det gjelder samfunnets utvikling? Hva som er siktemålene for skolen når det gjelder kulturell utvikling, og hva som er siktemålene når det gjelder elevers og læreres individuelle utvikling?

Generell del av læreplanen (fra L94/L97) framstår gjennomgående som mer orientert mot det sansende, estetiske, lekende, kollaborativt lærende og arbeidende mennesket, mens forslaget til ny overordnet del virker mer orientert mot individuell, effektiv og samfunnsnyttig læring og menneskers kognitive og kritiske evner og kompetanser. Vi er ikke overbevist om at denne verdiforskyvningen representerer et verdiløft. Eventuelt kan den representere en $\emptyset$ nsket verdiforskyvning - en forskyvning som Institutt for lærerutdanning ikke ønsker og er kritisk til.

1 Innlegget er basert på arbeid med høringsinnspill fra Institutt for lærerutdanning (ILU), NTNU, ført i pennen av Tone Pernille Østern, Maria Øksnes, Anders Sanne, Charlotte Gaertner og Camilla Stabel Jørgensen 


\section{LFRINGSSYN}

Vi savner et gjennomtenkt og helhetlig syn på læring som skal danne grunnlag for det pedagogiske, didaktiske, faglige og sosiale arbeidet i grunnutdanningen; et læringssyn som legger til rette for motiverende læring og tilpasset opplæring i form av variasjon og ulike innganger til ulike elevers læring.

I høringsutkastet har vi problemer med å identifisere et gjennomarbeidet syn på læring som de voksne som jobber i grunnutdanningen skal legge til grunn for sitt pedagogiske, didaktiske, faglige og sosiale arbeid. Læringssynet svinger gjennom høringsutkastet fra instrumentelt og individuelt til skapende og samarbeidende, men med en klar vekt på det første. Vi er motstandere av en slik forskyvning i det overgripende synet på læring med tanke på hva vi tror framtidens skole, barn og unge, trenger. Igjen kan vi se til Finland, som har et kapittel som heter «2.3. Syn på lærande», der det er flere momenter av interesse for Norge. Det handler bl.a. om å se barnet som aktiv, sansende og samarbeidende, kreativt og kritisk vurderende aktør i egen læring.

Institutt for lærerutdanning anbefaler at ny generell del av læreplanen får et eget kapittel der syn på læring gjøres rede for, og at det læringssyn som fremmes er helhetlig og godt gjennomtenkt.

I tillegg til ovennevnte mener vi at særlig tre sentrale deler av læringsbegrepet er mangelfullt behandlet i høringsutkastet. Disse er kroppslig læring, unders $\varnothing$ kende læring, samt estetisk og skapende læring. Vi anbefaler at disse løftes fram under et kapittel om syn på læring.

\section{OM Vedtatt Overordnet del}

Vi oppfatter at den overordnede delen slik den ble vedtatt i september 2017 er bedre enn høringsutkastet. I det vedtatte dokumentet forankres de føringene det gir tydeligere i aktuelle konvensjoner (urfolks rettigheter, barnekonvensjonen). Forankringen i formålsparagrafen er heller ikke svekket. I avsnittet om «Skaperglede, engasjement og utforskertrang» er det kommet inn et avsnitt om lek og lekens verdi; det er vi glade for. Vi oppfatter også at avsnittet «Prinsipper for læring, utvikling og danning » speiler en mer kompleks forståelse av læring og utvikling enn tilsvarende passasje i høringsutkastet. Likevel står definisjonen av kompetanse fast, og kunnskapssynet som tidligere preget læringsutbytteformuleringene, er dermed løftet opp til overordnet nivå. Om ny overordnet del er et verdiløft, eller en verdiforskyvning, er vi derfor fortsatt ikke sikre på. 


\title{
Om samarbeidet mellom hjem og skole
}

\author{
Av GunhiLd HageSETHER, professor em. i pedagogikk NLA Høgskolen. \\ E-post: Gunhild.Hagesaether@NLA.no
}

NLA Høgskolen tok opp flere momenter i sin uttalelse om høringsutkastet til Overordnet del - verdier og prinsipper (2017). Vi er av Prismets redaksjon spurt om å gjøre rede for det som ble sagt om skolens samarbeid med barnas hjem.

I uttalelsen minnet vi om at skolen som hjemmets hjelper i oppdragelsen har en lang tradisjon i norsk skole. Det ble også vist til FNs konvensjoner om menneskerettighetene, som Norge har lovfestet gjennom vedtak av Lov om styrking av menneskerettighetenes stilling i norsk rett. Andre lover må som en konsekvens av dette ta utgangspunkt $\mathrm{i}$ at det er foreldrene som har førsteretten til å bestemme hva slags undervisning og oppdragelse barna deres skal få.

I uttalelsen påpekte vi at å innlede overordnet del med å sitere formålsparagrafen, er en positiv måte å fremheve paragrafen som tolkningsgrunnlag for læreplanverket som helhet. I utkastet ble imidlertid bare ett avsnitt viet til samarbeidet med hjemmet, og dette avsnittet la større vekt på hjemmet som hjelper for skolen enn skolen som hjelper for hjemmet. Det ble sagt at foreldrene har kunnskap som skolen kan bruke, at hjemmets holdning til skolen har betydning for elevens engasjement og skoleinnsats, og at elevene i ulik grad har mulighet for å få hjelp og støtte i hjemmet. Videre sto det at foreldrene er de viktigste omsorgspersonene for barn og unge, men ikke at hjemmet har det primære ansvaret for deres oppdragelse og utvikling.

I uttalelsen minnet vi om at i Meld. St. 28 (2015-2016) skrev departementet: «En generell del skal få frem sentrale forutsetninger for et godt samarbeid mellom hjem og skole og understreke foreldrenes hovedansvar slik det er uttrykt i menneskerettighetene» (s. 20). Høringsutkastet nevnte imidlertid verken hjemmenes hovedansvar eller forankringen av dette i menneskerettighetene. NLA Høgskolen konkluderte sin høringsuttalelse med at hjemmets hovedansvar for barnets oppdragelse og utvikling fortsatt må ligge som en uttalt premiss for så vel samarbeidet mellom skole og hjem som for skolens arbeid for $\emptyset$ vrig.

Når det gjelder samarbeid mellom skole og hjem, er det etter vår mening vesentlige forbedringer i den vedtatte versjonen av Overordnet del - verdier og prinsipper for grunnopplcringen. Den mest iøynefallende er at det er satt inn en ny overskrift, «Samarbeid mellom skole og hjem». Her er stoff som i høringsutkastet var plassert under overskriften «Tilrettelegging for den enkelte elev», supplert med nytt stoff. På prinsipielt nivå er det viktigste at følgende setning er tatt inn: «Foreldrene og foresatte har hovedansvaret for barnets oppdragelse og utvikling». Nytt er det også at det står at skolen skal sørge for at foreldre og 
foresatte får nødvendig informasjon, og gis «mulighet til å ha innflytelse på sine barns skolehverdag» (se s. 17).

I og med at setningen om hjemmets hovedansvar er tatt inn, kan menneskerettsaspektet sies å være ivaretatt. Det er imidlertid verken vist til at foreldreretten er en menneskerettighet eller til Norges forpliktelse i denne sammenhengen. Regjeringens signal fra Meld. St. 28 (2015-2016) er altså bare delvis fulgt opp i læreplanverkets generelle del. Vi kunne ønsket en enda tydeligere fremheving av foreldreretten og betydningen av samarbeidet. Konklusjonene blir likevel at både foreldrenes status som hovedansvarlige for oppdragelsen, og samarbeidet mellom hjem og skole er vesentlig bedre ivaretatt i den endelige utgaven enn det var i høringsutkastet.

\section{Åndsmennesker? Skaperglede, kunst og meningssøken}

Av GUNNFRID LJONES ØIERUD, IKO - Kirkelig pedagogisk senter. E-post: g.l.oierud@iko.no

Den generelle delen av læreplanen (L94) inneholder mange utsagn om å stimulere mot og karakterstyrke, om viktigheten av estetiske erfaringer, at elever skal få oppleve gleden ved å møte kunstneriske uttrykk og selv utfolde skapende krefter, om å stimulere livslyst, fantasi til å tenke nytt og allmenndannelse som gjør det rikt og spennende å leve sammen. IKO påpekte i vårt høringssvar at det var knapt med formuleringer som dette i utkastet til ny overordet del, og at noe viktig da blir borte. Formålsparagrafen sier at elevene skal få utfolde skaperglede og utforskertrang, at opplæringen skal «opne dører mot verda og framtida» og bygge på verdien åndsfrihet. Stortingsmelding 28 (2015-2016) side 19 refererer at «Komiteen fremhevet at en fornyet generell del skal bidra til å $\emptyset$ ke oppmerksomheten på grunnopplæringens brede dannelsesmandat». Vi påpekte at disse føringene ikke var godt nok ivaretatt i høringsutkastet.

IKO skrev at vi er opptatt av det hele mennesket, og ser at mennesket som «åndsmenneske» underbetones i høringsutkastet: Mennesket som skapende, mennesket som spirituelt/religiøst og med spørsmål om mening, mennesket som lar seg berøre, bevege og forundre av møtet med noe utenfor seg selv, mennesket med fantasi og undring, mennesket med mot til å gå utenfor de opptråkka stiene, mennesket som får breie erfaringer og får drive med noe simpelthen for å fă gode opplevelser og utforske det livet kan gi. Dette gjelder utkastet som helhet, men vi trakk særlig fram noen delkapittel:

Under avsnittet Skaperglede, engasjement og utforskertrang (1.4) sto det i forslaget at «elevene skal få utfolde sine skapende krefter gjennom sansning og tenkning», og i det omkringliggende ble det betont at utforsking er viktig for 
å få faglig kunnskap og finne løsninger på praktiske og teoretiske problemer. Det sto også at «elever som lærer om skapende områder utvikler evne til å gi stemme til erfaringer, finne svar på spørsmål og løse problemer». Vi uttrykte at dette peker mot en for smal forståelse av det skapende. Å skape gjennom å sanse og tenke er ikke nok - å utfolde skaperglede må innebære selv å kunne forme og uttrykke noe. Og det å lære om skapende områder kan ikke erstatte det selv å få skape, utforske og uttrykke. Det skapende mennesket framstår i denne delen av høringsutkastet mer som en problemløser som lærer om noe skapende, enn en som selv opplever gleden ved å forme noe, uttrykke noe og få til noe skapende. Estetiske og eksistensielle uttrykk er ikke knyttet til utkastets tolkning av skaperglede, og praktiske og fysiske aspekter ved det skapende er underbetont.

Danning og helhetlig kompetanse er et delkapittel i utkastet som består av kun to korte avsnitt, der det andre avsnittet ikke handler om bred dannelse, men om samfunnets behov for kompetanse og arbeidskraft. I setningen «Opplæringen må legge til rette for at arbeidslivet får tilgang på kvalifisert arbeidskraft» er det mennesket som produksjonsressurs som betones - ikke det helhetlig dannede mennesket. IKO skrev at dette delkapittelet bør uttrykke det brede dannelsesoppdraget tydeligere. I dette bør det også klarere gis rom for elevene som åndsmennesker, og vi nevnte konkret at religion/livssyn også bør nevnes blant hva elever skal få møte som grunnlag for utvikling. IKO bemerket også at «mening» i beskrivelsen av «Folkehelse og livsmestring» framstår primært som å unngå opplevelser av meningsløshet knyttet til vanskelige livssituasjoner og dårlig psykisk helse, og at vi synes at meningsfylde bør forstås bredere enn dette.

Nokså langt på vei synes vi den vedtatte overordna delen imøtekommer innspillene våre på dette området.

\section{Et godt nok forslag til ny overordnet del av laereplanen?}

Av AnN Midtrun, avdelingsleder Avdeling for religion og pedagogikk, Det teologiske menighetsfakultetet. E-post:Ann.Midttun@mf.no

MF leverte en relativt kritisk høringsuttalelse til forslaget om ny generell del. Utkastet inneholdt viktige anliggender som vi kunne støtte, men vi hadde likevel grunnleggende innvendinger mot dokumentet som et overordnet verdidokument for skolens virksomhet. Høringsutkastet var i for stor grad gjennomsyret av en forståelse av opplæring som et mål- og styringsverktøy, noe som styrker de instrumentalistiske tendensene i norsk skole. Vi etterlyste en videreføring av verdiperspektivene og det brede opplæringssynet i daværende Generell del og 
Meld St. 28 (2015-2016), slik Stortinget hadde vedtatt. Etter vår mening manglet dokumentet en samlende visjon eller idé for skolens virksomhet, og språket var byråkratisk og av svært ujevn kvalitet, noe som også fikk betydning for det faglige innholdet. Ikke minst hadde vi kritiske innvendinger til utmyntingen av skolens verdigrunnlag, beskrivelsen av skolens oppgave og av elev- og læringssynet i dokumentet. Noen få eksempler på disse tendensene i høringsuttalelsen:

Ny generell del og nye læreplaner skal bidra til et verdiløft i skolen ved at formålsparagrafens fellesverdier innlemmes i alle skolens fag. Etter vår mening ga ikke høringsutkastet god nok hjelp til det. Avsnittet om Opplæringens verdigrunnlag preges av generelle eller uklare formuleringer om verdier. Verdiene fremstilles som noe som først og fremst skal gis elevene og i mindre grad erfares av elevene eller utvikles i samhandling med andre. Høringsutkastets beskrivelse av Norge som et enhetlig samfunn med felles verdier, blir for unyansert. Skolen skal gi hjelp til at elevene skal orientere seg i et mangfoldig samfunn, i et spenningsfelt av verdier, verditolkninger og verditradisjoner. Her etterlyste vi også mer vekt på skolens helhetlige samfunnsmandat og dannelsesoppdrag.

Vi kritiserte også det dominerende individualistiske og smale perspektivet på «kunnskapsutveksling og læring». I altfor stor grad vektlegges hva den enkelte elev skal oppnå og prestere. Det handler om «ambisjoner», «mestring», «god fremtid» osv. Mange formuleringer i utkastet peker mot skolens rolle som tilrettelegger for den velfungerende og tilpassede elevens læring og utvikling. Vi mente at et overordnet dokument for norsk skole må formidle et elevsyn som handler om å gi den enkelte en opplevelse og erfaring av ubetinget verdi, anerkjennelse og tilstrekkelighet.

Nå er ny Overordnet del - verdier og prinsipper for grunnopplaringen vedtatt. Den har stort sett beholdt grunnstrukturen fra høringsutkastet, kompetansebegrepet er relativt uendret, og opplæring forstått som et mål- og styringsverktøy er fortsatt dominant. Men etter vår mening er dette dokumentet likevel mer i tråd med Meld. St. 28 (2015-2016) når det gjelder språklig presisjon og vektlegging av sentrale perspektiver, som samspillet mellom dannelse og kunnskap og mellom elev, skole og samfunn. Departementet må ha lyttet til råd fra høringsinstansene, og mange høringsinstanser må ha påpekt noe av det samme. Det har skjedd en perspektivforskyvning fra hva den enkelte eleven skal tilegne seg og lære, til hva som er skolens oppgave som dannings- og læringsarena. Opplæringens verdigrunnlag er mer konkretisert, og kan gi hjelp til arbeidet med læreplaner og skolemiljø. Verdier er ikke bare noe som skal læres, men må tas i bruk og kjempes for. Elevene blir også skrevet inn som mer selvstendige og skapende aktører. Mangfoldperspektivet er blitt tydeligere, men vi beklager at «religion» er tatt ut som begrep i beskrivelsen av dette mangfoldet (s. 14). 


\section{Tverrfaglighet og barekraftig utvikling.}

Av Ole Andreas Kvamme, stipendiat i etikkdidaktikk, Institutt for læererutdanning og skoleforskning, Universitetet i Oslo. E-post: o.a.kvamme@ils.uio.no

Et viktig signal i ny overordnet del er en fornyet satsing på tverrfaglighet i norsk skole. Satsingen presenteres i kapittel 2 som tar for seg prinsipper for læring, utvikling og danning.

Begrunnelsen for tverrfaglighet knyttes til tre konkrete temaer - folkehelse og livsmestring, demokrati og medborgerskap, samt bærekraftig utvikling. «Kunnskapsgrunnlaget for å finne løsninger på problemer innenfor temaene finnes i mange fag, og temaene skal bidra til at elevene oppnår forståelse og ser sammenhenger på tvers av fag», heter det i ny overordnet del.

Mange spørsmål er ikke delt opp i skolefag, og derfor skal elevene lære å se skolefag i sammenheng. Dette er et godt argument for tverrfaglig arbeid. Et problem er imidlertid at verden heller ikke er delt inn i tre tverrfaglige temaer. Ny overordnet del unngår faktisk å peke på sammenhenger mellom temaene. Da er det nærliggende å tenke at de bør behandles atskilt. Dette problemet vil jeg her kort belyse med vekt på bærekraftig utvikling. FN og UNESCO har tatt en rekke initiativer for å fremme «utdanning for bærekraftig utvikling» med nasjonale oppfølginger verden over, også i Norge. Bærekraftig utvikling er altså ikke noe nytt tema, heller ikke i norsk skole. Men i satsingen både nasjonalt og internasjonalt betones sammenhenger mellom temaer som i overordnet del framstår som atskilte

I den tidligere norske satsingen på utdanning for bærekraftig utvikling (strategiene fra 2006 og 2012) er helse, deltakelse og demokrati faglige tema som «er sentrale i opplæring for bærekraftig utvikling.» (Utdanningsdirektoratets «Utdanning for bærekraftig utvikling» 2006, s. 6). En lignende vektlegging finner vi på europeisk nivå, dvs. i UNECEs strategi for utdanning for bærekraftig utvikling som Norge har bidratt inn i. Der er både medborgerskap, demokrati, personlig helse og miljømessig helse framhevet som nøkkelområder innenfor bærekraftig utvikling. I FN-sammenheng ble bærekraftsfeltet utvidet da organisasjonen høsten 2015 vedtok de 17 bærekraftsmålene. Nå er helse blitt et eget bærekraftsmål, og medbestemmelse og medvirkning er framhevet i flere mål.

Det kan gi god mening å arbeide med ett av de tre tverrfaglige temaene i skolen uten at linjer alltid må trekkes til de andre to. Men like selvsagt er det at utdanning for bærekraftig utvikling involverer både demokratisk danning, folkehelse og livsmestring. Slike sammenhenger blir synlige når temaet blir konkret, for eksempel knyttet til elevers frykt og håp for framtida.

2 Denne kommentaren baserer seg på forskergruppen COSER (UV-fakultetet, Universitetet i Oslo) sitt høringssvar. Gruppen ledes av Marianne Ødegaard. På de punktene som tas opp her, førte ikke innspillene våre til endringer. Av den grunn viser jeg kun til endelig versjon av overordnet del. 
To forhold forsterker det nokså nedtonede inntrykket av bærekraftig utvikling i ny overordnet del. Det ene handler om struktur. Bærekraftig utvikling presenteres et stykke ut $\mathrm{i}$ kapittel 2 som ett av tre tverrfaglige tema. Med en mer overordnet plassering ville utfordringene for pedagogikk og skoleutvikling blitt markert. Dette er foreløpig lite utforsket i Norge.

Det andre forholdet handler om humanistiske fags plass i satsingen, og med det også kulturens rolle. FNs fjerde bærekraftsmål er rettet mot utdanning. Under delmål 4.7 er utdanning for bærekraftig utvikling framhevet spesielt, delmålet er også sitert av Stortinget $\mathrm{i}$ behandlingen av Stortingsmelding 28 (2015-2016). Her heter det at elever skal tilegne seg en kompetanse som omfatter «verdsetting av kulturelt mangfold og kulturens bidrag til bærekraftig utvikling.» Dette gjør humanistiske skolefag til en selvskreven del av satsingen. Kulturens betydning for bærekraftig utvikling er likevel ikke berørt i ny overordnet del.

Så er det grunn til å legge til at sammenhenger som ikke er påpekt i overordnet del, likevel kan bli synlige i norsk skole i forbindelse med fagfornyelsens arbeid med læreplanene nå.

\section{«Livsmestring» i lareplanverket}

Av GEIR SkEIE, professor ved Universitetet i Stavanger og Stockholms universitet. E-post: geir.skeie@uis.no

Mitt perspektiv på ny overordna del skal kun dreie seg om avsnittet under Tverrfaglige tema som heter «Folkehelse og livsmestring». Dette er en tematikk som ikke har vært så tydelig til stede i læreplaner for grunnskolen tidligere, og det er derfor grunn til å spørre seg hvilke konsekvenser det vil kunne få at helseperspektiver er kommet såpass tydelig inn.

Bakgrunnen for innspillet er mine erfaringer fra å arbeide parallelt i Norge og Sverige gjennom snart ti år. I vårt naboland ser det ut til at helseperspektiver har stått vesentlig sterkere i skolen enn vi er vant med i Norge. Dette skjer ikke minst gjennom det som heter «elevhälsa» hvor arbeidet med elevens helse bygger på et bredt helsebegrep og har som mål at elevenes læringsmiljø og læringssituasjon skal bli best mulig, men også at de skal ha det bra totalt sett: ${ }^{3}$ «Elevhälsan omfattar medicinska, psykologiska, psykosociala och specialpedagogiska insatser. Syftet med att samla insatserna var bland annat att öka samverkan och att betona det hälsofrämjande och förebyggande arbetet. Elevhälsans mål är att skapa en

3 Se Skolverket/socialstyrelsen: Vägledning för elevhälsan: http://www.socialstyrelsen.se/Lists/Artikelkatalog/Attachments/20394/2016-11-4.pdf Skolverket redovisning av regeringsuppdrag: https://www.skolverket.se/om-skolverket/publikationer/sok?_xurl_=http\%3A\%2F\%2Fwww5.skolverket.se\%2Fwtpub\%2Fws\%2 Fskolbok\%2Fwpubext\%2Ftrycksak\%2FBlob\%2Fpdf3746.pdf\%3Fk\%3D3746 
så positiv lärandesituation som möjligt för eleven» (vägledning) «Det finns ett starkt samband mellan lärande och hälsa, och det hälsofrämjande arbetet är därför viktigt såväl för elevernas välbefinnande som för en ökad måluppfyllelse.» (regeringsuppdraget). Gjennom «elevhälsa» er koblingen tydelig mellom skolens virksomhet og det profesjonelle medisinske og psykologiske feltet, samtidig som helsebegrepet og dermed siktemålet blir svært omfattende.

Det er i dette lys jeg ser avsnittet om folkehelse og livsmestring. «Folkehelse» knytter forbindelsen til det medisinske systemet, mens «livsmestring» kan se ut til å referere bredt til hele bredden $\mathrm{i}$ hvordan man håndterer livet og hverdagen. Det som er særlig interessant $i$ en religions- og livssynssammenheng, er at dette er det eneste stedet i overordnet del at ordet «mening» brukes om noe som nærmer seg det eksistensielle. Ordene «religion» og «livssyn» er nemlig knapt nevnt utenom sitatene fra opplæringslova. Man kan derfor si at eksistensielle spørsmål og svar, slik disse kan spores i overordnet del, tilsynelatende fristilles fra religioner og livssyn og snarere knyttes til menneskers helse og velbefinnende. Selv om dette kan bety at religioner og livssyn gis en plass som mulige ressurser til et bedre liv, så er det satt inn i et temmelig instrumentelt preget perspektiv.

En annen måte å tolke dette på, vil være i forlengelsen av et forskningsprosjekt som jeg ledet i Sverige og som så på faget «livskunskap» i svensk skole. Dette hadde dukket opp «nedenfra», som en betegnelse skolene selv brukte på en del av sin virksomhet som arbeidet med at elevene skulle ha det bedre både med seg selv og andre. Internasjonalt er dette inspirert av «lifeskills»-tenkning og av tendenser som gjerne kalles «terapeutisk utdanning», ikke ulikt det som den norske forskeren Ole Jacob Madsen har vært opptatt av fra et psykologisk perspektiv (Ole Jacob Madsen: Den terapeutiske kultur, Oslo, Universitetsforlaget, 2017). I en artikkel basert på dette prosjektet pekte vi på de tendenser som finnes til at religion og religiøsitet kan dukke opp på uventede steder i skolen, og likne på helsefremmende virksomhet (Zetterqvist \& Skeie 2014, «Religion i skolen; her, der og hvor-som-helst?» i Norsk Pedagogisk Tidsskrift, 98(5), 304-315). Poenget med dette er ikke å kritisere sosioemosjonelle forebyggende programmer som for eksempel er basert på mindfulness, men å påpeke at de nå har fått en bredere arena i skolen gjennom den nye overordnede delen. Min spådom er at vi vil få økende tilbud til skolen fra både skolemedisinsk, psykologisk og alternativ medisinsk sektor begrunnet i deres potensiale for $\emptyset \mathrm{kt}$ livsmestring. Når man tenker på den $\emptyset$ konomiske, ideologiske og verdimessige status som helsesektoren har i vår tid, kan dette vise seg å bli en viktig utfordring. For religionsdidaktikere vil utfordringen snarere være å tilby noen analytiske verktøy å møte denne flora av livsmestrings-tilbud med. På den ene siden kan det være viktig å peke på de spirituelle og religiøse røtter som ikke 